\title{
Effects of Heat Treatment and Si Addition on the Mechanical Properties of 0.1 wt $\%$ C TRIP-aided Cold-rolled Steels
}

\author{
Chang Gil LEE, Sung-Joon KIM, Chang-Seok OH and Sunghak LEE ${ }^{1)}$ \\ Materials Processing Department, Korea Institute of Machinery and Materials, Changwon 641-010 Korea. \\ 1) Center for Advanced Aerospace Materials, Pohang University of Science and Technology, Pohang $790-784$ Korea.
}

(Received on March 25, 2002; accepted in final form on June 18, 2002)

\begin{abstract}
The purpose of the present study was understanding the effects of heat treatment and silicon content on the microstructure and mechanical properties of low-carbon TRIP-aided cold-rolled steel sheets. Two steels of the same base composition, $0.10 \% \mathrm{C}-1.5 \% \mathrm{Mn}-\mathrm{Si}-0.5 \% \mathrm{Cu}$ (hereafter all in weight percent), but containing $0.94 \% \mathrm{Si}$ and $1.48 \%$ Si were cold rolled to $1 \mathrm{~mm}$ thick sheet. The sheets were intercritically annealed and isothermally treated in the temperature range of bainite reaction in order to vary the volume fraction of retained austenite and the mechanical properties. The fractions of retained austenite increased with decreasing intercritical annealing and isothermal treatment temperatures, resulting in the improvement in tensile strength, elongation, and the strength-ductility balance. In the steel having the higher silicon content, a higher fraction of retained austenite and better mechanical properties were achieved than in the steel having the lower silicon content. The findings indicate that partitioning of $\mathrm{C}$ and $\mathrm{Mn}$ to the austenite during intercritical annealing, together with a higher Si content, increase the stability of the austenite and affect the optimum intercritical and isothermal heat treatment temperatures.
\end{abstract}

KEY WORDS: TRIP-aided cold-rolled steels; low carbon; multiphase; Si effect; heat treatment; mechanical properties; retained austenite.

\section{Introduction}

Recently, demands for high-strength cold-rolled steel sheets from industries, automotive industry in particular, have been rapidly increasing in order to improve safety as well as to reduce weight. TRIP (transformation induced plasticity)-aided cold-rolled steel sheets have also received increasing attention as steels having both high strength and high ductility because of the martensitic transformation of retained austenite during plastic deformation. ${ }^{1-4)}$ Since the first TRIP-aided steels were developed by Zackay et al., ${ }^{5)}$ many studies have been made in this area. A considerable amount of retained austenite can be obtained, together with excellent tensile strength and ductility, when cold-rolled $\mathrm{C}-\mathrm{Mn}-\mathrm{Si}$ steels are heated up to the $(\alpha+\gamma)$ two phase region and then isothermally treated for several minutes in the temperature range of bainite reaction. A conventional continuous annealing line (CAL) can be easily applied to the isothermal treatment. ${ }^{5-8)}$ Studies on TRIP-aided coldrolled steels have mainly focused on the cases of the carbon content of $0.2-0.4 \mathrm{wt} \%$. These medium-carbon TRIP-aided cold-rolled steels have many advantages in mechanical properties over conventional high-strength cold-rolled steels. However, weldability, which is an important property required for cold-rolled steels, can deteriorate because of the high carbon content. In order to overcome this shortcoming, more studies are required to lower the carbon content.

It is known that silicon, a major alloying element in
TRIP-aided cold-rolled steels, plays an important role, ${ }^{9-11)}$ and is expected to substantially contribute to the mechanical property improvement and to the higher volume fraction of retained austenite in cold-rolled steels containing lower carbon than conventional TRIP-aided ones. To assure the strength and ductility improvement from stabilized retained austenite in low-carbon C-Mn-Si TRIP-aided cold-rolled steels, an optimum combination of alloying elements and optimum conditions for intercritical annealing (annealing in the $(\alpha+\gamma)$ region) and isothermal treatment should be established so that the effect of alloying elements can be maximized.

Meanwhile, the addition of copper to $\mathrm{C}-\mathrm{Mn}-\mathrm{Si}$ TRIPaided steels was confirmed to contribute to the enhancement of strength and elongation by the present authors, ${ }^{12)}$ although copper was known as a harmful element due to its hot shortness. Thus, in the present study, two compositions of cold-rolled steel sheets in which the carbon content was lowered to $0.10 \%$ and $0.5 \%$ of copper was also present were fabricated. Investigations were made into how variations in the intercritical annealing and isothermal treatment conditions and in the silicon content affected the mechanical properties and the volume fractions of retained austenite of cold-rolled steel sheets.

\section{Experimental Procedure}

\subsection{Melting and Rolling}

Two kinds of steel ingots, named as S1 and S2, were fab- 
Table 1. Chemical compositions (wt\%) and transformation temperatures $\left({ }^{\circ} \mathrm{C}\right)$ measured using a dilatometer of the steels investigated.

\begin{tabular}{cccccccc}
\hline Steel & $\mathrm{C}$ & $\mathrm{Mn}$ & $\mathrm{Si}$ & $\mathrm{Cu}$ & $\mathrm{A}_{\mathrm{Cl}}$ & $\mathrm{A}_{\mathrm{C} 3}$ & $\mathrm{Ms}$ \\
\hline \hline $\mathrm{S} 1$ & 0.10 & 1.51 & 0.94 & 0.49 & 738 & 882 & 445 \\
$\mathrm{~S} 2$ & 0.10 & 1.52 & 1.48 & 0.51 & 755 & 907 & 449 \\
\hline \hline
\end{tabular}

Table 2. Heat-treatment conditions of the cold-rolled steel sheets.

\begin{tabular}{ccccc}
\hline Steel & $\begin{array}{c}\text { Intercritical } \\
\text { Annealing } \\
\text { Temperature }\left({ }^{\circ} \mathrm{C}\right)\end{array}$ & $\begin{array}{c}\text { Intercritical } \\
\text { Annealing } \\
\text { Time (min.) }\end{array}$ & $\begin{array}{c}\text { Isothermal } \\
\text { Treatment } \\
\text { Temperature }\left({ }^{\circ} \mathrm{C}\right)\end{array}$ & $\begin{array}{c}\text { Isothermal } \\
\text { Treatment } \\
\text { Time (min.) }\end{array}$ \\
\hline \hline S1 & 810,780 & 5 & 450,470 & $1,3,5,10,20$ \\
S2 & 830,810 & 5 & & \\
\hline
\end{tabular}

ricated by vacuum induction melting. Table 1 lists their chemical compositions, and $\mathrm{A}_{\mathrm{Cl}}, \mathrm{A}_{\mathrm{C} 3}$, and martensite transformation starting temperatures (Ms) measured using a dilatometer. Steel ingots were rough-rolled into slabs of $25 \mathrm{~mm}$ in thickness. The slabs were homogenized at $1250^{\circ} \mathrm{C}$ for two hours, hot-rolled into sheets of $3 \mathrm{~mm}$ in thickness. The finish rolling temperature was $900^{\circ} \mathrm{C}$. The hot-rolled steel sheets were pickled by a $10 \% \mathrm{HCl}$ solution of $80^{\circ} \mathrm{C}$, and were cold-rolled into sheets of $1 \mathrm{~mm}$ in thickness.

\subsection{Intercritical Annealing and Isothermal Treatment}

The conditions of intercritical annealing and isothermal treatment are significantly affecting the formation of retained austenite and the subsequent mechanical properties in TRIP-aided cold-rolled steels. ${ }^{1,13-14)}$ In this study, the intercritical annealing was conducted at the temperature range of $780-830^{\circ} \mathrm{C}$ for five minutes using a salt bath. The isothermal treatment was carried out in the temperature range of $450-470^{\circ} \mathrm{C}$ for $1-20 \mathrm{~min}$, and then air-cooled. Table 2 summarizes the heat-treatment conditions of the present study.

\subsection{Evaluation of Mechanical Properties}

Tensile specimens (longitudinal direction) with a gage length of $25.4 \mathrm{~mm}$ and a width of $6.3 \mathrm{~mm}$ were prepared from the cold-rolled steel sheets. The tensile specimens were deformed at room temperature at a crosshead speed of $2 \mathrm{~mm} / \mathrm{min}$ using a tensile tester, and yield strength, tensile strength and elongation were measured. The lower yield point was adopted as yield strength in the case of yield point phenomenon, whereas $0.2 \%$ offset value in the case of continuous yielding.

\subsection{Microstructural Observation}

Since C-Mn-Si TRIP-aided steels have very complex microstructures composed of ferrite, bainite and/or martensite, and retained austenite, identification of each phase is unclear when etched in a nital solution. A sodium metabisulfite solution $\left(\mathrm{Na}_{2} \mathrm{~S}_{2} \mathrm{O}_{3} \cdot \mathrm{H}_{2} \mathrm{O} \quad 10 \mathrm{~g}+\mathrm{H}_{2} \mathrm{O} \quad 100 \mathrm{~m} l\right)$ was used in conjunction with the nital etching to identify the phases. When the specimens etched by the sodium metabisulfite solution are observed by an optical microscope, it is easier to define the phases since ferrite is displayed light or dark gray, bainite or martensite as black, while retained austenite as white. ${ }^{12)}$

\subsection{Volume Fraction Measurement of Retained Austenite}

Volume fraction of the retained austenite was measured using an X-ray diffractometer (XRD). Mo- $\mathrm{K}_{\alpha}$ characteristic $\mathrm{X}$-ray was used, and the volume fraction of retained austenite, $V_{\gamma}$, was calculated from the integrated intensity of ferrite and austenite peaks using the equation, $V_{\gamma}=$ $1.4 I_{\gamma} /\left(I_{\alpha}+1.4 I_{\gamma}\right) .{ }^{15,16)}$ Here, $I_{\gamma}$ is the average integrated intensity obtained at $\{220\}_{\gamma}$ and $\{311\}_{\gamma}$ peaks, and $I_{\alpha}$ is that obtained at $\{211\}_{\alpha}$ peak.

\section{Results}

\subsection{Microstructural Variation vs. Heat Treatment}

Figure 1 presents optical micrographs of the $\mathrm{S} 1$ steel after the isothermal treatment at $450^{\circ} \mathrm{C}$, when the isothermal treatment time and the intercritical annealing temperature are varied. When the specimens are quenched into water after the intercritical annealing at a certain temperature between $\mathrm{A}_{\mathrm{C} 1}$ and $\mathrm{A}_{\mathrm{C} 3}$, austenite formed during the intercritical annealing transforms into martensite. Thus, the volume fraction of ferrite and austenite can be determined through the image analyzing method after the intercritical annealing. The volume fraction ratio of ferrite and austenite formed at $810^{\circ} \mathrm{C}$ was about $40: 60$, while at $780^{\circ} \mathrm{C}$ about $50: 50$. In the case of the intercritical annealing temperature of $810^{\circ} \mathrm{C}$, being $\left(\mathrm{A}_{\mathrm{C} 1}+\mathrm{A}_{\mathrm{C} 3}\right) / 2$, the ferrite fraction increases as the isothermal treatment time becomes longer, whereas the fraction of secondary phases displayed gray or black decreases. This tendency is relaxed more or less as the intercritical annealing temperature is lowered. When the S1 steel was intercritically annealed at $780^{\circ} \mathrm{C}$, the fraction of secondary phases is reduced compared to the case of $810^{\circ} \mathrm{C}$.

Figure 2 shows optical micrographs of the S2 steel isothermally treated at $450^{\circ} \mathrm{C}$. The overall microstructural variation tends to be similar to that of the S1 steel. The ferrite fraction increases with increasing the isothermal treatment time, and this tendency is less visible as the intercritical annealing temperature drops from $830^{\circ} \mathrm{C}$, being $\left(\mathrm{A}_{\mathrm{C} 1}+\mathrm{A}_{\mathrm{C} 3}\right) / 2$, to $810^{\circ} \mathrm{C}$ at which the fraction ratio of ferrite and austenite is $50: 50$.

Figures 3(a) and 3(b) are optical micrographs of the S1 and S2 steels after they were etched by a sodium metabisulfite solution. Figures 3(a) and 3(b) show the S1 steel intercritically annealed at $780^{\circ} \mathrm{C}$ and the $\mathrm{S} 2$ steel intercritically annealed at $810^{\circ} \mathrm{C}$, respectively, followed by the isothermal treatment at $450^{\circ} \mathrm{C}$ for $5 \mathrm{~min}$. The retained austenites are homogeneously distributed all over the microstructure, and most of them coexist with nearby ferrite, bainite or martensite, whereas some are isolated inside ferrite grains.

\subsection{Mechanical Properties and Volume Fraction of Retained Austenite}

Figure 4 summarizes the tensile properties and the fraction of retained austenite of the S1 steel. The heat-treatment conditions are shorthanded in Fig. 4 with two numbers linked by a hyphen, such as $810-450$, meaning that the specimen was intercritically annealed at $810^{\circ} \mathrm{C}$ and then isothermally treated at $450^{\circ} \mathrm{C}$. Tensile strength and elonga- 


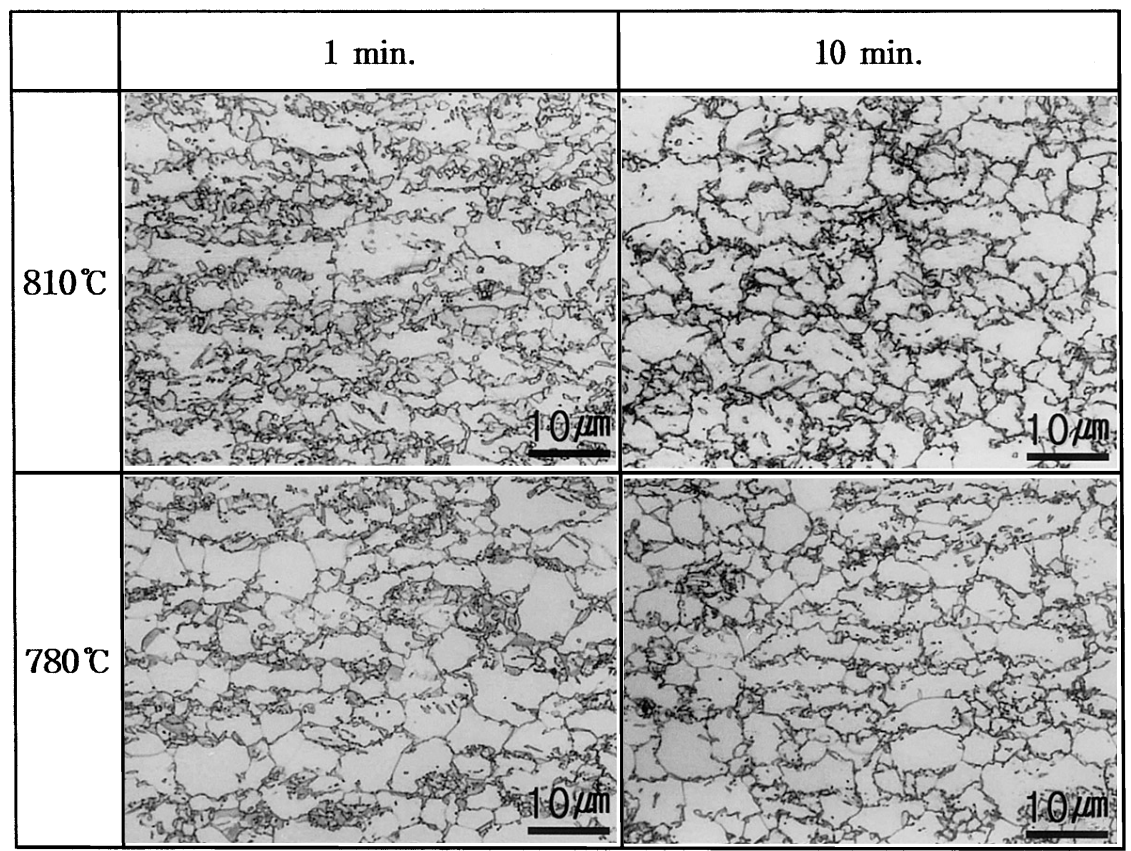

Fig. 1. Optical micrographs of the $\mathrm{S} 1$ steel intercritically annealed at $810^{\circ} \mathrm{C}$ and $780^{\circ} \mathrm{C}$ and isothermally treated at $450^{\circ} \mathrm{C}$ for 1 and 10 min (etched by a $2 \%$ nital solution).

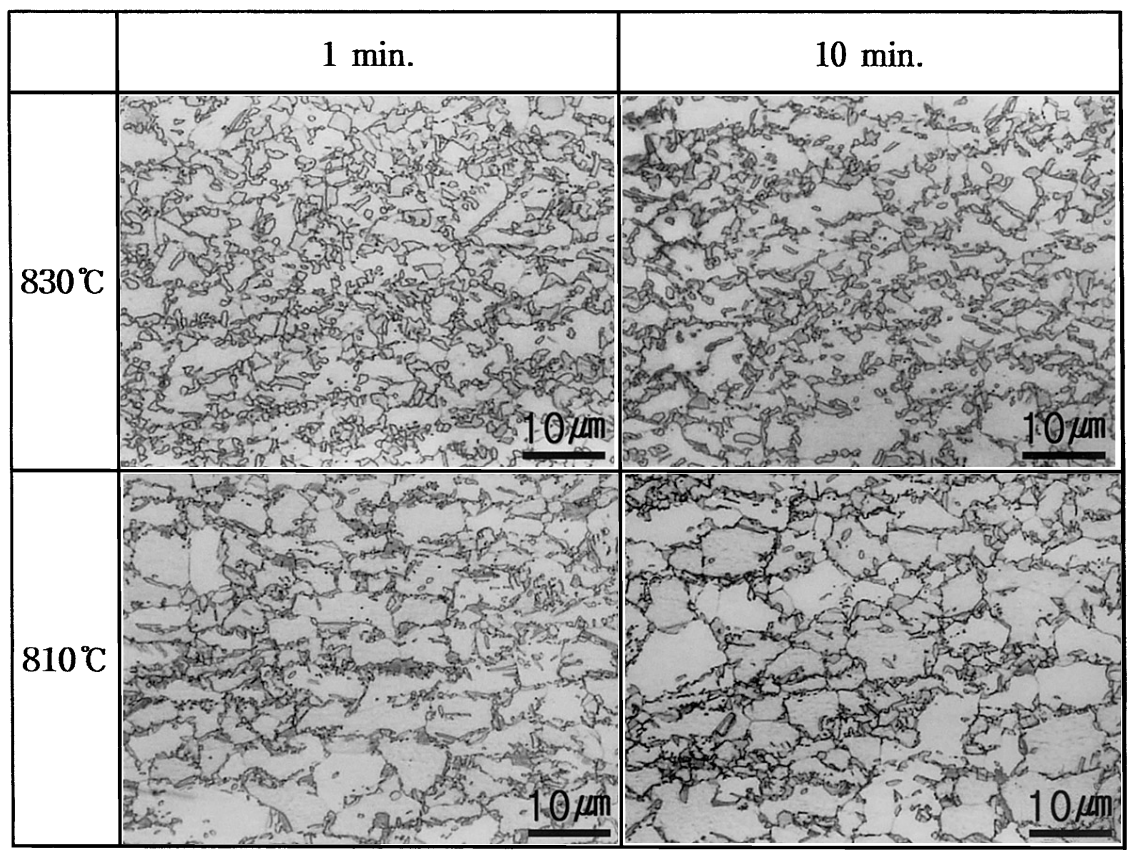

Fig. 2. Optical micrographs of the $\mathrm{S} 2$ steel intercritically annealed at $830^{\circ} \mathrm{C}$ and $810^{\circ} \mathrm{C}$ and isothermally treated at $450^{\circ} \mathrm{C}$ for 1 and $10 \mathrm{~min}$ (etched by a $2 \%$ nital solution).

tion decrease, but yield strength considerably increases with increasing the isothermal treatment time, irrespective of the intercritical annealing temperature. Comparing the mechanical properties with the intercritical annealing temperature, yield strength at $780^{\circ} \mathrm{C}$ is lower than that at $810^{\circ} \mathrm{C}$ by about $30 \mathrm{MPa}$, but tensile strength stays about the same level, while elongation and strength-ductility balance are high. Comparing the cases of isothermal treatment at $450^{\circ} \mathrm{C}$ and at $470^{\circ} \mathrm{C}$ following intercritical annealing at $780^{\circ} \mathrm{C}$, the former shows higher tensile strength, elongation, and strength-ductility balance than the latter. Such variations in mechanical properties are closely related with the fraction of retained austenite. The variations in the fraction of retained austenite as to the intercritical annealing temperature and the isothermal treatment temperature and time are found quite substantial. In the case of the intercritical annealing temperature of $810^{\circ} \mathrm{C}(810-450$ specimens), the fraction of retained austenite is close to $10 \%$ when the isothermal treatment time is $1 \mathrm{~min}$, but is reduced down to $2 \%$ when isothermally treated for $10 \mathrm{~min}$. When intercritically annealed at $780^{\circ} \mathrm{C}(780-450$ specimens), it is slightly over $10 \%$ at the initial stage of isothermal treatment, and then decreases to about $4 \%$ after 10 -min isothermal treatment; this case thus shows the higher fraction of retained 


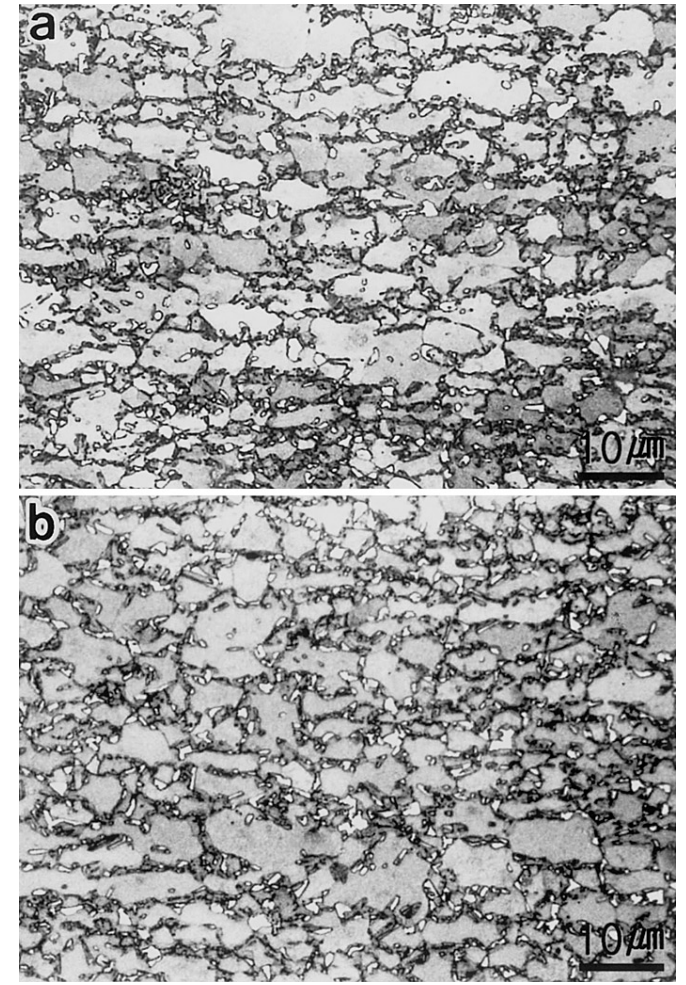

Fig. 3. Optical micrographs of (a) the $\mathrm{S} 1$ steel intercritically annealed at $780^{\circ} \mathrm{C}$ and isothermally treated at $450^{\circ} \mathrm{C}$ for $5 \mathrm{~min}$ and (b) the $\mathrm{S} 2$ steel intercritically annealed at $810^{\circ} \mathrm{C}$ and isothermally treated at $450^{\circ} \mathrm{C}$ for $5 \mathrm{~min}$ (etched by a sodium metabisulfite solution).

austenite overall than the $810^{\circ} \mathrm{C}$ case. Isothermal treatment at $450^{\circ} \mathrm{C}(780-450$ specimens) also shows the higher fraction of retained austenite in comparison with $470^{\circ} \mathrm{C}(780$ 470 specimens).

Figure 5 presents the mechanical properties and the fraction of retained austenite of the $\mathrm{S} 2$ steel, whose overall tendency is similar to the case of the S1 steel as observed in Fig. 4. However, the mechanical property variation as to the isothermal treatment time is smaller here. The fraction variation of retained austenite is also smaller, and shows a reduction of about $2-4 \%$ as a function of isothermal holding time when isothermally treated at $450^{\circ} \mathrm{C}(810-450$ specimens). As in the case of the S1 steel of Fig. 4, the steel intercritically annealed at $810^{\circ} \mathrm{C}$ at which the fraction ratio of ferrite and austenite is 50:50 and isothermally treated at $450^{\circ} \mathrm{C}(810-450$ specimens) has the higher retained austenite fraction, together with better mechanical properties overall. It is found from Figs. 4 and 5 that lowering intercritical annealing temperature and isothermal treatment temperature works more favorably for the increased fraction of retained austenite and the subsequent improvement in strength and elongation.

\subsection{Effect of Silicon Addition on Mechanical Prop- erties and Retained Austenite Fraction}

Figure 6 shows the variations in the mechanical property and the fraction of retained austenite of the S1 and S2 steels intercritically annealed at the temperature, at which the fraction ratio of ferrite and austenite is $50: 50\left(780^{\circ} \mathrm{C}\right.$ for the $\mathrm{S} 1$ steel and $810^{\circ} \mathrm{C}$ for the $\mathrm{S} 2$ steel) and then isothermally treated at $450^{\circ} \mathrm{C}$, as a function of the isothermal

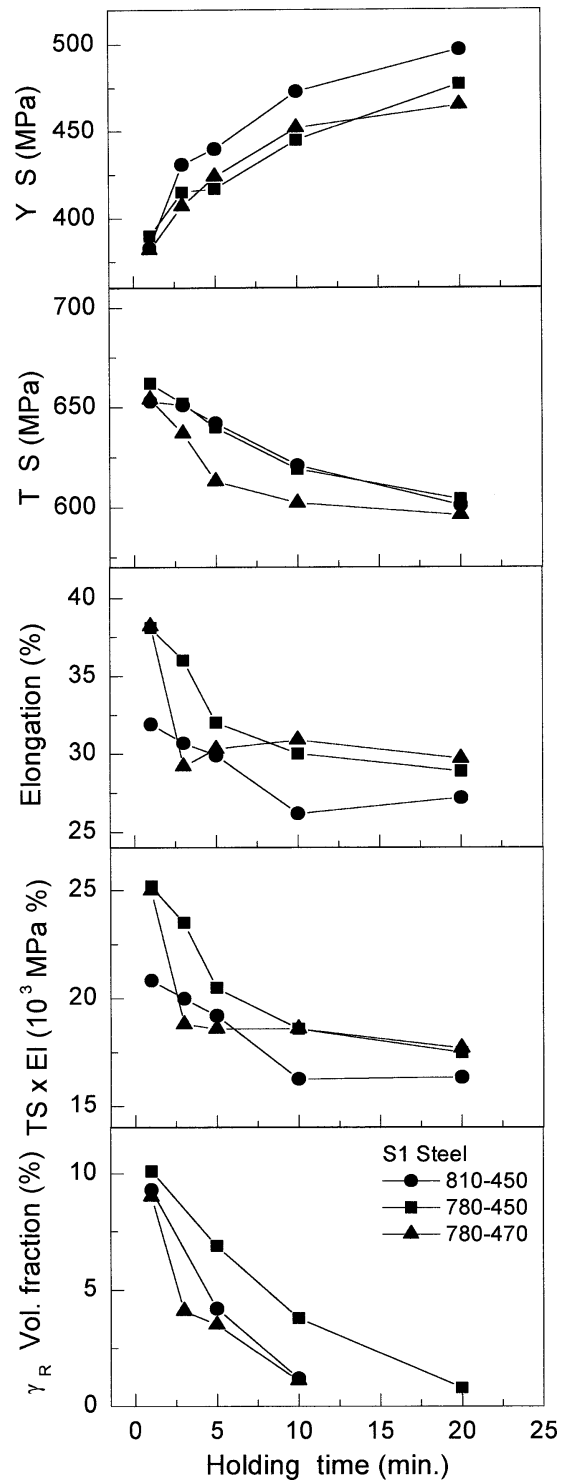

Fig. 4. Tensile properties and retained austenite volume fractions of the $\mathrm{S} 1$ steel intercritically annealed at $810^{\circ} \mathrm{C}$ and $780^{\circ} \mathrm{C}$ for $5 \mathrm{~min}$ and isothermally treated at $450^{\circ} \mathrm{C}$ and $470^{\circ} \mathrm{C}$.

treatment time. The S2 steel having higher silicon content has much higher tensile strength and slightly higher elongation than the S1 steel, whereas its yield strength is similar or a bit lower, thereby showing more excellent strengthductility balance than the S1 steel. This is because the S2 steel has the higher fraction of retained austenite than the S1 steel. Particularly because of the relatively smaller variation in the retained austenite fraction of the S2 steel as to the isothermal treatment time, mechanical properties also vary to a lesser degree. Thus, the mechanical properties of low-carbon cold-rolled steel sheets can be improved considerably by increasing the silicon content. It is also more beneficial to increase the silicon content for higher strength and ductility by TRIP effect.

\section{Discussion}

Microstructures and fractions of retained austenite of cold-rolled steels substantially vary with the intercritical annealing conditions due to the redistribution of solute ele- 


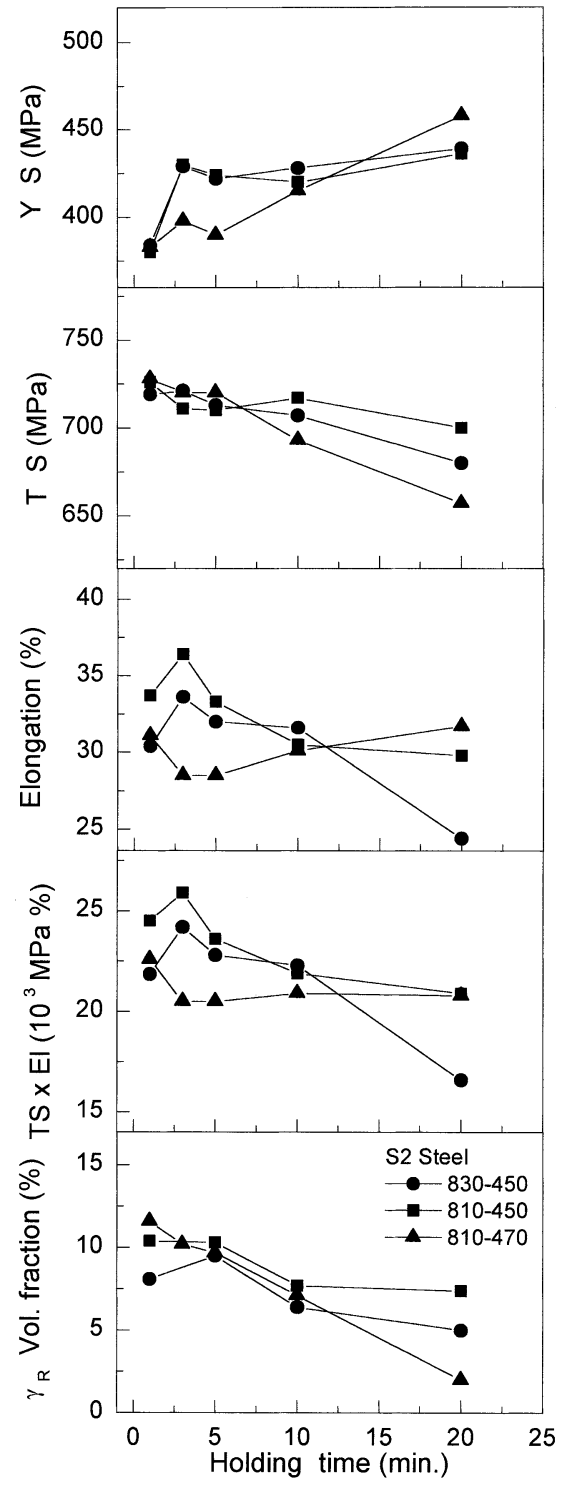

Fig. 5. Tensile properties and retained austenite volume fractions of the S2 steel intercritically annealed at $830^{\circ} \mathrm{C}$ and $810^{\circ} \mathrm{C}$ for $5 \mathrm{~min}$ and isothermally treated at $450^{\circ} \mathrm{C}$ and $470^{\circ} \mathrm{C}$.

ments, particularly carbon. At a higher intercritical annealing temperature, the austenite fraction increases, but a large amount of retained austenite cannot be obtained because the carbon content in austenite decreases. At too a low intercritical annealing temperature, the carbon content in austenite can increase, but the obtainable amount of retained austenite is also reduced because of the low austenite fraction. Many researchers have reported that the intercritical annealing temperature to obtain the higher fraction of retained austenite is $\left(\mathrm{A}_{\mathrm{C} 1}+\mathrm{A}_{\mathrm{C} 3}\right) / 2 .{ }^{1,11,13,17)}$ In the cases of the $\mathrm{S} 1$ and $\mathrm{S} 2$ steels, when intercritically annealed at $810^{\circ} \mathrm{C}$ and $830^{\circ} \mathrm{C}$, being $\left(\mathrm{A}_{\mathrm{C} 1}+\mathrm{A}_{\mathrm{C} 3}\right) / 2$, respectively, the austenite fractions were measured as about $60 \%$. On the contrary, when intercritically annealed at $780^{\circ} \mathrm{C}$ and $810^{\circ} \mathrm{C}$ at which the austenite fraction was about $50 \%$, both the S1 and S2 steels showed an increased fraction of retained austenite, together with improved properties. These results indicate that the intercritical annealing should be conducted at a temperature at which the stability of austenite can be raised by increased concentration of alloying elements in austenite by

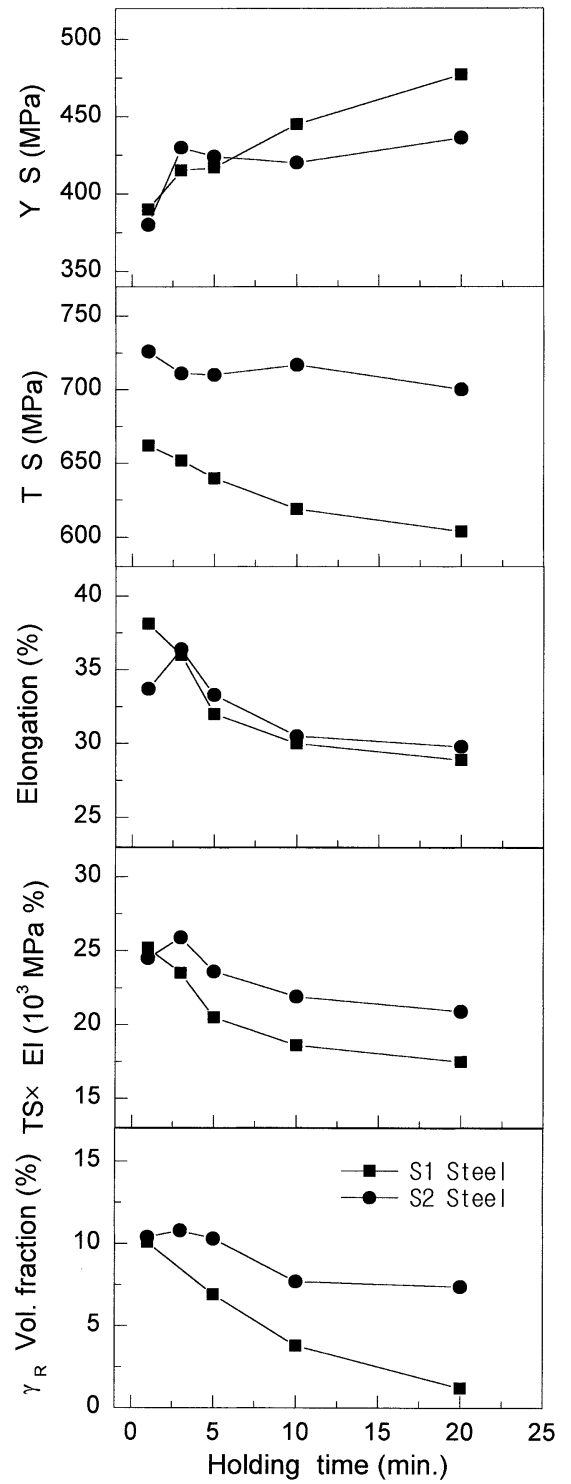

Fig. 6. Tensile properties and retained austenite volume fractions of the $\mathrm{S} 1$ steel intercritically annealed at $780^{\circ} \mathrm{C}$ and isothermally treated at $450^{\circ} \mathrm{C}$ and the $\mathrm{S} 2$ steel intercritically annealed at $810^{\circ} \mathrm{C}$ and isothermally treated at $450^{\circ} \mathrm{C}$.

lowering the fraction of austenite formed during the intercritical annealing. When the intercritical annealing temperature is set too low, the mechanical properties do not improve much because the fraction of retained austenite is reduced due to the reduction of the absolute amount of austenite and because retained austenite with higher stability than an appropriate stability level is formed. ${ }^{12,13,17)}$ According to the investigations into the effects of the intercritical annealing and the aforementioned results, the appropriate temperature is the one at which the fraction ratio of ferrite and austenite is 50:50. The authors confirmed similar results in cold-rolled $0.15 \% \mathrm{C}-1.5 \% \mathrm{Mn}-1.5 \% \mathrm{Si}$ steels, which have slightly higher carbon content than the steels of the present study, but lower than the conventional TRIP-aided cold-rolled steels. ${ }^{13}$

Mechanical properties of TRIP-aided cold-rolled steels also significantly vary with the isothermal treatment conditions. It was reported that the isothermal treatment at $\mathrm{Ms}+\left(20-30^{\circ} \mathrm{C}\right)$ produced highest fraction of retained 
austenite and excellent mechanical properties. ${ }^{17,18)}$ However, when the $\mathrm{S} 1$ and $\mathrm{S} 2$ steels were isothermally treated at $470^{\circ} \mathrm{C}\left(\mathrm{Ms}+20^{\circ} \mathrm{C}\right)$, the fraction of retained austenite was low, and the mechanical properties were not good in comparison with the case of the isothermal treatment at $450^{\circ} \mathrm{C}$ (Ms). When isothermally treated at $450^{\circ} \mathrm{C}$, the bainitic transformation can be more active than the case of $470^{\circ} \mathrm{C}$ in shorter time, and the formation of retained austenite can be accelerated.

In the isothermal treatment, the austenite formed during the intercritical annealing is transformed to bainite. Austenite stabilizers such as carbon and manganese are mostly soluble in the austenite during the intercritical annealing. Therefore, the chemical composition of the austenite formed during the intercritical annealing differs from the overall composition of the cold-rolled steel, and the transformation point of them, particularly Ms point, becomes lower than the Ms point of the steel. When the S1 or S2 steel is intercritically annealed at $780^{\circ} \mathrm{C}$ or $810^{\circ} \mathrm{C}$, at which the fraction ratio of ferrite and austenite is $50: 50$, the manganese content in austenite becomes about $2 \%$ as that in ferrite is assumed to be $0.5 \%$ according to the $\mathrm{Fe}-\mathrm{Mn}$ binary phase diagram. ${ }^{19)}$ Assuming that all the carbon is dissolved in austenite, disregarding the carbon solubility in ferrite, the carbon concentration in the intercritical austenite can be calculated as $0.2 \%$. Thus, austenite having $0.2 \%$ carbon and $2.0 \%$ manganese is formed during the intercritical annealing. As the isothermal treatment time is increased, the carbon concentration in the remained austenite becomes higher, and the Ms temperature of the austenite gradually decreases, thereby forming metastable retained austenite at room temperature. In the TTT diagram of a $0.23 \% \mathrm{C}-1.86 \% \mathrm{Mn}$ steel, ${ }^{20)}$ which has a composition similar to that of the austenite formed during the intercritical annealing in the $\mathrm{S} 1$ or $\mathrm{S} 2$ steel, the nose temperature of the bainite transformation curve is about $430^{\circ} \mathrm{C}, 30^{\circ} \mathrm{C}$ higher than the Ms point. Thus, the lower isothermal treatment temperature is more favorable for improved mechanical properties of the S1 and S2 steels. In this respect, it is possible to lower the isothermal treatment temperature below $450^{\circ} \mathrm{C}$. Taking into consideration of the chemical composition of austenite formed during the intercritical annealing of the S1 and S2 steels and the isothermal transformation curve $^{20)}$ of a steel having a similar chemical composition, it can be expected that they have higher fraction of retained austenite and better mechanical properties when they are isothermally treated at $430^{\circ} \mathrm{C}$ than at $450^{\circ} \mathrm{C}$.

Besides the establishment of the optimum heat-treatment conditions, also important is the selection of appropriate alloy composition. The S2 steel showed somewhat lower yield strength than the S1 steel, but much higher tensile strength and a similar elongation (Fig. 6). Since both steels were intercritically annealed under the same condition, i.e., at the temperature at which the fraction ratio of ferrite and austenite is $50: 50$ and then isothermally treated at $450^{\circ} \mathrm{C}$, the differences in the fractions of retained austenite and mechanical properties are attributed to the difference in the silicon content. According to Sawai et al., ${ }^{21)}$ who studied the effects of alloying elements on the formation of retained austenite in C-Mn-Si TRIP-aided cold-rolled steels, silicon had stronger effect than manganese. Silicon contributes to higher fraction of retained austenite and its ability to increase the carbon concentration in adjacent austenite since silicon prevents the carbide precipitation in bainite and increases carbon content as well during the isothermal treatment. ${ }^{9-11,21)}$ Thus, the S2 steel with higher silicon content can have higher retained austenite fraction and better mechanical properties than the S1 steel, when both were intercritically annealed and isothermally treated under the same conditions. It is confirmed that the addition of silicon works favorably for the formation of a larger amount of stabilized retained austenite, particularly in low-carbon TRIP-aided cold-rolled steels, since the decrease of the fraction of retained austenite due to the low carbon content can be compensated by the silicon addition, together with improvement in mechanical properties.

Significance of this study lies with the finding that coldrolled steels having lower carbon content than conventional TRIP-aided steels can have high strength and ductility through appropriate alloy design and proper heat-treatment conditions.

\section{Conclusions}

Following conclusions were reached in this study after conducting intercritical annealing, isothermal treatment, microstructural observation, and evaluation of mechanical properties and retained austenite fraction on two low-carbon cold-rolled steel sheets specifically designed to improve the weldability.

(1) $0.1 \% \mathrm{C}$ low-carbon cold-rolled steels whose carbon content is lower than conventional high-strength TRIPaided cold-rolled steels can also have high strength and ductility by establishing appropriate intercritical annealing and isothermal treatment conditions.

(2) There exists an appropriate intercritical annealing temperature range according to alloying elements. When the S1 or S2 steel is intercritically annealed at the temperature range where the austenite fraction is about $50 \%$, the highest retained austenite fraction and the best mechanical properties are obtained.

(3) In order to insure high fraction of retained austenite and excellent mechanical properties in low-carbon TRIPaided cold-rolled steels, the isothermal treatment temperature should be determined in consideration of the fraction and composition of austenite formed during the intercritical annealing.

(4) Higher silicon content in low-carbon TRIP-aided cold-rolled steels favors higher fraction of retained austenite and leads to improved mechanical properties.

\section{Acknowledgements}

This work was financially supported by the Ministry of Science and Technology (MOST) of Korea. The authors acknowledge the support.

\section{REFERENCES}

1) K. Sugimoto, N. Usui, M. Kobayashi and S. Hashimoto: ISIJ Int., 32 (1992), 1311.

2) K. Sugimoto, M. Kobayashi and S. Hashimoto: Metall. Trans. A, 23A (1992), 3085.

3) H. C. Chen, H. Era and M. Shimizu: Metall. Trans. A, 20A (1989), 437. 
4) S. K. Kim, H. C. Shin, J. H. Chung and Y. W. Chang: J. Korean Inst. Met. Mater, 36 (1998), 151.

5) V. F. Zackay, E. R. Parker, D. Fahr and R. Bush: Trans. Am. Soc. Met., 60 (1967), 252.

6) J. G. Shin: Master Thesis, POSTECH, Pohang, (1993).

7) O. Matsumura, Y. Sakuma and H. Takechi: Scr. Metall., 21 (1987), 1301.

8) Y. Sakuma, O. Matsumura and H. Takechi: Metall. Trans. A, 22A (1991), 489.

9) H. K. D. H. Bhadeshia and D. V. Edmonds: Metall. Trans. A, 10A (1979), 895.

10) I. Tsukatani, S. Hashimoto and T. Inoue: ISIJ Int., 31 (1991), 992.

11) W. C. Jeong and J. H. Chung: Mater. Charact., 26 (1991), 53.

12) D. B. Im, C. G. Lee, S. J. Kim and I. M. Park: J. Korean Inst. Met.
Mater, 38 (2000), 447

13) C. G. Lee, S. J. Kim, S. G. Park and I. D. Choi: J. Korean Inst. Met. Mater, 36 (1998), 1382.

14) W. G. Leslie and G. C. Ranch: Metall. Trans. A, 9A (1978), 343.

15) R. L. Miller: Trans. Am. Soc. Met., 57 (1964), 892.

16) R. L. Miller: Trans. Am. Soc. Met., 61 (1968), 592.

17) J. H. Chung: Ph. D. Thesis, POSTECH, Pohang, (1994).

18) Y. Sakuma, D. K. Matlock and G. Krauss: J. Heat Treat., 8 (1990), 109.

19) T. B. Massalski: Binary Alloy Phase Diagrams, 2nd Ed., Vol. 2, ASM, Metals Park, OH, (1990), 1725.

20) Y. C. Jung: Ph. D. Thesis, Ehime Univ., (1997), 24.

21) I. Sawai, S. Uchida and E. Kamisaka: Tetsu-to-Hagané, 71 (1985), 1292. 